GRASAS Y ACEITES 66 (4)

October-December 2015, e100

ISSN-L: 0017-3495

doi: http://dx.doi.org/10.3989/gya.0227151

\title{
Advanced olive selections with enhanced quality for minor constituents
}

\author{
L. Velasco, ${ }^{\mathrm{a},}$ R. De la Rosa ${ }^{\mathrm{b}}$ and L. León ${ }^{\mathrm{b}}$ \\ ${ }^{a}$ Instituto de Agricultura Sostenible (IAS-CSIC), Alameda del Obispo s/n, 14004 Córdoba, Spain \\ ${ }^{b}$ IFAPA Centro Alameda del Obispo, Avda. Menéndez Pidal s/n, 14004, Córdoba, Spain \\ ${ }^{\square}$ Corresponding author: 1velasco@ias.csic.es
}

Submitted: 02 February 2015; Accepted: 20 May 2015

SUMMARY: Squalene, phytosterols and tocopherols are minor constituents of paramount importance for the olive fruit and oil quality. The objective of this research was to conduct a two-year evaluation of these compounds in the fruits of seven advanced breeding selections. They were mainly selected for early bearing and high oil content from progenies of crosses between the cultivars 'Arbequina' and 'Picual'. An analysis of variance showed high genotypic effects, non-significant year effects, and genotype x year interactions of low magnitude. The selections showed great variability for the traits, surpassing in some cases the parental values. One selection with total tocopherol content of $263 \mathrm{mg} \cdot \mathrm{kg}^{-1}$ fruit flesh, compared to a maximum of $148 \mathrm{mg} \cdot \mathrm{kg}^{-1}$ in the parents, and another one with $\Delta^{5}$-avenasterol concentration of $30.7 \%$ of total sterols, compared to a maximum of $22.1 \%$ in the parents, were the most relevant phenotypes. These selections may play an important role for improving olive fruit and oil quality for specific market niches.

KEYWORDS: Breeding; Fruit quality; Olive; Phytosterols; Squalene; Tocopherols

RESUMEN: Selecciones avanzadas de olivo con calidad mejorada para compuestos menores. Compuestos como el escualeno, los fitoesteroles y los tocoferoles tienen una enorme importancia para la calidad del fruto y del aceite de oliva. El objetivo de este trabajo fue la evaluación durante dos años de estos compuestos en los frutos de siete selecciones avanzadas de olivo, seleccionadas principalmente para entrada temprana en producción y alto contenido en aceite a partir de las descendencias de cruzamientos entre los cultivares 'Arbequina' y 'Picual'. El análisis de la varianza mostró, para la mayoría de los caracteres, un elevado efecto del genotipo, ausencia de efecto del factor año, e interacciones entre año y genotipo de baja magnitud. Las selecciones mostraron gran variabilidad para todos los caracteres, sobrepasando en algunos casos los valores de los parentales. Entre las selecciones con valores superiores a los parentales, destacaron una selección con un contenido en tocoferoles de $263 \mathrm{mg} \cdot \mathrm{kg}^{-1}$ pulpa frente a un máximo de $148 \mathrm{mg} \cdot \mathrm{kg}^{-1}$ en los parentales, y otra selección con una concentración de $\Delta^{5}$-avenasterol del $30.7 \%$ del total de esteroles, frente a un máximo de $22.1 \%$ en los parentales. Estas selecciones pueden desempeñar un papel importante en la mejora de la calidad del fruto y el aceite de oliva para determinados segmentos de mercado.

PALABRAS CLAVE: Calidad de fruto; Escualeno; Fitoesteroles; Mejora; Olivo; Tocoferoles

Citation/Cómo citar este artículo: Velasco L, De la Rosa R, León L. 2015. Advanced olive selections with enhanced quality for minor constituents. Grasas Aceites 66 (4): e100. doi: http://dx.doi.org/10.3989/gya.0227151.

Copyright: (C) 2015 CSIC. This is an open-access article distributed under the terms of the Creative Commons Attribution-Non Commercial (by-nc) Spain 3.0 Licence. 


\section{INTRODUCTION}

The olive is one of the most ancient domesticated tree crops (Besnard et al., 2013). Olive oil consumption is considered a hallmark of the traditional Mediterranean diet, which has been associated with reduced mortality caused by cardiovascular diseases (Psaltopoulou et al., 2004). The beneficial nutritional properties of olive oil were traditionally associated with its high content in monounsaturated oleic acid, in contrast to higher poly-unsaturation levels in seed oils until comparative studies with higholeic seed oils suggested an additional role of minor constituents (Pérez-Jiménez et al., 1995). Minor components in olive oil associated with health-promoting effects include polar phenolic compounds, squalene, tocopherols, and sterols (Boskou, 2009).

The necessity of breeding efforts in olive has not been as evident as in other fruit species (Byrne, 2012). In fact, systematic breeding programs have been scarce until very recently, producing only a limited number of cultivars so far (Bellini et al., 2008). The main objectives in olive breeding are early bearing, high productivity, resistance to biotic and abiotic stresses, suitability to different growing systems, mechanical harvesting aptitude, and oil content and quality (León et al., 2008; Fabbri et al., 2009). At the first stages of olive breeding, the focus is mainly placed on vigor and fruit traits. Fruit and oil quality traits are generally considered only in the last selection steps. Several authors have reported improved cultivars/ advanced selections with enhanced oleic acid, tocopherol, and/or total phenolic contents (Manaï et al., 2007; Baccouri et al., 2007; Ripa et al., 2008; León et al., 2011; De la Rosa et al., 2013). Practically no breeding research has been conducted on other oil quality traits such as squalene and phytosterols.

Squalene is one of the most biologically active constituents of olive oil due to its powerful antioxidant and anti-carcenogenic properties (Sotiroudis and Kyrtopoulos, 2008). Chemically, squalene is a terpenoid hydrocarbon synthesized as a biochemical intermediate at the initial steps of the phytosterol biosynthesis. Virgin olive oil is the richest vegetable source of squalene (Boskou, 2009). Phytosterols are compounds that play an important nutritional role by reducing cholesterol absorption due to their similar chemical structure and biological function as cholesterol (Piironen et al., 2000). From a technological perspective, phytosterols such as $\Delta^{5}$-avenasterol that contain an ethylidene group in their structure confer higher antioxidant activity at frying temperatures than other sterols (Rossell, 2001). The presence of this sterol in olive oil has been associated with retarded polymerization in heated triacylglycerols (Boskou, 2011). Tocopherols are compounds with free radical scavenging activity, both in vivo (vita$\min \mathrm{E}$ ) as well as in vitro. $\alpha$-tocopherol, which is the tocopherol homologue with the highest vitamin $\mathrm{E}$ activity (Eitenmiller and Lee, 2004), is the predominant tocopherol form in olive oil (Boskou, 2009). Total tocopherol content in olive oil is much lower than in seed oils, including sunflower oil that also contains primarily $\alpha$-tocopherol (Gunstone and Harwood, 2007).

One of the main constraints for the selection of oil quality traits is the scarce information about their genetic control and heritability (Fabbri et al., 2009). Most of the studies have focused on the fatty acid profile, with several studies reporting a great genotypic effect for the concentration of the major fatty acids and subsequent feasibility of selection for this trait (Ayton et al., 2001; León et al., 2008; Ripa et al., 2008; Rjiba et al., 2010; De la Rosa et al., 2013). For total phenolic content, the effect of the genotype has been found to be non-significant (Ripa et al., 2008) or of very low magnitude (El Riachy et al., 2011). Conversely, the genotypic effect was reported to be slightly higher than the year effect for tocopherol content, with low genotype $\times$ year interaction (Beltrán et al., 2010). Temperature and rainfall are the main environmental factors which influence olive oil quality (Aparicio and Luna, 2002). Beltrán et al. $(2005,2010)$ reported higher tocopherol content associated with lower rainfall, though a similar effect has not been observed for different irrigation levels (Gómez-Rico et al., 2007). Irrigation has been found to significantly influence the squalene content of olive oil (Martinelli et al., 2012). The altitude at which the trees are grown and the degree of maturity of the fruits are also two important factors affecting olive oil quality (Aparicio and Luna, 2002).

Seven olive breeding seedlings coming from crosses between the cultivars 'Arbequina' and 'Picual' were initially selected for their early cropping and oil content (León et al., 2004). The selections have been previously evaluated for fruit traits and fatty acid composition (De la Rosa et al., 2013). The objective of this research was to evaluate the variability for squalene content and tocopherol and phytosterol contents and profiles in those selections.

\section{MATERIALS AND METHODS}

The Spanish cultivars 'Picual' and 'Arbequina' and seven breeding selections derived from crosses between them, namely UC-I-22-90, UC-I-2-35, UC-I-32-78, UC-I-36-41, UC-I-36-43, UC-I-37-69, and UC-I-4248 were used. A detailed pedigree of the selections was previously reported (De la Rosa et al., 2013). A field trial was established in an open field in Cabra (Córdoba, Spain) in June 2007 at $6 \times 5 \mathrm{~m}$ spacing using plants propagated by semi-hardwood stem cuttings. A random sample of around $500 \mathrm{~g}$ of fruits was collected from three trees per genotype (replications) in mid-November of 2010 and 2011. Average maximum, mean and minimum temperature and rainfall for both years are shown in Table 1. The ripening 
TABLE 1. Average annual minimum temperature (Tmin), maximum temperature (Tmax), mean temperature (Tmean), and total rainfall in the experimental field in 2010 and 2011.

\begin{tabular}{ccccc} 
Year & $\mathbf{T} \min \left({ }^{\circ} \mathbf{C}\right)$ & $\operatorname{Tmax}\left({ }^{\circ} \mathbf{C}\right)$ & Tmean $\left({ }^{\circ} \mathbf{C}\right)$ & Rainfall $(\mathbf{m m})$ \\
\hline 2010 & 11.0 & 21.4 & 15.9 & 1058 \\
2011 & 12.2 & 23.3 & 17.3 & 491 \\
\hline
\end{tabular}

index at the time of harvest, averaged over the two years, was 3.5 for 'Picual' and 2.8 for 'Arbequina'. The ripening index for the selections ranged from 2.0 (UC-I-36-43) to 3.8 (UC-I-37-69). Considering all the genotypes, the ripening index was higher in 2010 (3.45) than in 2011 (2.48). More detailed information on the ripening index of individual selections was reported by De la Rosa et al. (2013).

A subsample of around $30 \mathrm{~g}$ was stored at $-80^{\circ} \mathrm{C}$ shortly after harvest and lyophilized. The stones were then removed and the flesh was milled in a laboratory ball mill. The ground samples were then stored at $-20{ }^{\circ} \mathrm{C}$ and analyzed in duplicate for squalene content, phytosterol content and profile, and tocopherol content and profile following procedures previously reported (Velasco et al., 2014).

Data were analyzed by the General Linear Model procedure of IBM SPSS Statistics version 20.0 (IBM Corp., Armonk, NY, USA) using the following model:

$$
Y i j=\mu+G i+Y j+G Y i j+\varepsilon i j
$$

Where: Yij is the observation of genotype $\mathrm{i}$ in year $\mathrm{j} ; \mu$ is the general mean; $\mathrm{Gi}$ and $\mathrm{Yj}$ are effects of genotype $\mathrm{i}$ and year $\mathrm{j}$, respectively; GYij is genotype $\times$ year interaction of genotype $i$ with year $j$, and eijr is the residual error of genotype i in year $\mathrm{j}$. Genotypes and years were considered as random variables. Pearson's correlation coefficients among oil quality traits were computed using IBM SPSS Statistics 20.0.

\section{RESULTS}

The analysis of variance revealed a significant effect of genotype for all the traits, whereas the year effect was only significant for tocopherol content and campesterol and $\gamma$-tocopherol concentrations (Table 2). The case of tocopherol content was particularly relevant, as the effect of year was much higher than the genotypic effect. The average tocopherol contents were $123 \mathrm{mg} \cdot \mathrm{kg}^{-1}$ in 2010 and $180 \mathrm{mg} \cdot \mathrm{kg}^{-1}$ in 2011 . The genotype $\times$ year effect was significant for most of the traits, except for squalene content and concentrations of campesterol and stigmasterol in the phytosterol fraction. When significant, the genotype $\times$ year effect was in all cases of low magnitude compared to the main effects.

The cultivars 'Arbequina' and 'Picual' showed very contrasting levels for most of the traits, particularly for squalene contents (1800 and $5207 \mathrm{mg} \cdot \mathrm{kg}^{-1}$ dry flesh weight, respectively), phytosterol contents $\left(1485\right.$ and $1109 \mathrm{mg} \cdot \mathrm{kg}^{-1}$ dry flesh weight, respectively), phytosterol profile (e.g. $\Delta^{5}$-avenasterol concentration of 22.1 and $10.2 \%$ of total phytosterols, respectively), and tocopherol profile (e.g. $\alpha$-tocopherol concentration of 99.1 and $92.2 \%$ of total tocopherols, respectively) (Table 3). The breeding selections derived from them showed great variability for all the traits, covering in most cases the ranges of variation between the parents and presenting for some of the traits lower or higher levels than the parents, e.g. for phytosterol content, concentrations of stigmasterol, $\beta$-sitosterol and $\Delta^{5}$-avenasterol, and total tocopherol content (Table 3). The selection UC-I-36-41 showed a significantly lower phytosterol content than both parents, whereas no selection with significantly higher phytosterol content was identified (Table 3). For phytosterol profile, the selection UC-I$2-35$ had a lower $\beta$-sitosterol concentration $(62.6 \%$ of total sterols) and a higher $\Delta^{5}$-avenasterol concentration $(30.7 \%)$ than both parents, whereas UC-I-36-41 showed a higher stigmasterol concentration (Table 3 ). The selection UC-I-37-69 exhibited a higher tocopherol content $\left(263.2 \mathrm{mg} \cdot \mathrm{kg}^{-1}\right.$ fruit flesh) than both parents $\left(125.0 \mathrm{mg} \cdot \mathrm{kg}^{-1}\right.$ in 'Picual' and $147.9 \mathrm{mg} \cdot \mathrm{kg}^{-1}$ in 'Arbequina'). Phenotypes with higher levels than the parents for the mentioned traits were observed for both years. This is shown in Figure 1 for squalene, phytosterol and tocopherol contents, and the concentration of $\Delta^{5}$-avenasterol. No significant correlations among traits were observed in the average values of

TABLE 2. Analysis of variance (mean squares) for squalene content $\left(\mathrm{mg} \cdot \mathrm{kg}^{-1}\right.$ dry fruit flesh), tocopherol content (mg $\cdot \mathrm{kg}^{-1} \mathrm{dry}$

fruit flesh), concentration of $\alpha$ - and $\gamma$-tocopherol ( $\%$ of total tocopherols), phytosterol content ( $\mathrm{mg}^{\cdot} \mathrm{kg}^{-1} \mathrm{dry} \mathrm{fruit} \mathrm{flesh),} \mathrm{and}$ concentrations of campesterol, stigmasterol, $\beta$-sitosterol, and $\Delta^{5}$-avenasterol ( $\%$ of total sterols) in the fruits of seven advanced olive selections and their progenitors 'Arbequina' and 'Picual', grown in Cabra (Córdoba) in 2010 and 2011.

\begin{tabular}{|c|c|c|c|c|c|c|c|c|c|c|}
\hline & $D f^{a}$ & Squalene & Phytosterol & Campesterol & Stigmasterol & $\beta$-sitosterol & $\Delta^{5}$-avenasterol & Tocopherol & $\alpha-\mathbf{T}$ & $\gamma-\mathbf{T}$ \\
\hline Genotype $^{\mathrm{b}}$ & 8 & $11119134^{* *}$ & $437332^{* *}$ & $5.5^{* *}$ & $1.3^{* *}$ & $243.3^{* *}$ & $244.1^{* *}$ & $11514^{* *}$ & $24.2^{* *}$ & $22.9^{* *}$ \\
\hline Year & 1 & $653915^{\mathrm{ns}}$ & $18460^{\mathrm{ns}}$ & $3.7^{* *}$ & $0.6^{\mathrm{ns}}$ & $3.0^{\mathrm{ns}}$ & $13.4^{\mathrm{ns}}$ & $43814^{* *}$ & $0.1^{\mathrm{ns}}$ & $9.6^{*}$ \\
\hline GxY & 8 & $219379^{\mathrm{ns}}$ & $33439^{* *}$ & $0.3^{\mathrm{ns}}$ & $0.1^{\mathrm{ns}}$ & $33.7^{* *}$ & $26.8^{* *}$ & $1338^{*}$ & $1.3^{* *}$ & $1.6^{* *}$ \\
\hline Error & 36 & 220096 & 9649 & 1.0 & 0.2 & 5.3 & 5.0 & 544 & 0.1 & 0.1 \\
\hline
\end{tabular}

${ }^{\mathrm{a}} \mathrm{df}=$ Degree of freedom.

$\mathrm{b}_{* *}=$ significant at $P \leq .01 ; *=$ significant at $P \leq 0.05$; ns $=$ not significant at $P \leq 0.05$. 
TABLE 3. Two-year average values for squalene content ( $\mathrm{mg} \cdot \mathrm{kg}^{-1} \mathrm{dry}$ fruit flesh), tocopherol content $\left(\mathrm{mg} \cdot \mathrm{kg}^{-1} \mathrm{dry}\right.$ fruit flesh), concentration of $\alpha$ - and $\gamma$-tocopherol ( $\%$ of total tocopherols), phytosterol content ( $\mathrm{mg} \cdot \mathrm{kg}^{-1}$ dry fruit flesh), and concentrations of campesterol, stigmasterol, $\beta$-sitosterol, and $\Delta^{5}$-avenasterol ( $\%$ of total sterols) in the fruits of olive cultivars 'Arbequina' and 'Picual' and seven advanced selections derived from them, grown in Cabra (Córdoba) in 2010 and 2011.

\begin{tabular}{lrrccccccc}
\hline & Squalene & Phytosterol & Campesterol & Stigmasterol & $\beta$-sitosterol & $\Delta^{\mathbf{5}}$-avenasterol & Tocopherol & $\alpha$-T & $\gamma$-T \\
\hline Arbequina & 1800 & 1485 & 3.2 & 0.7 & 72.8 & 22.1 & 147.9 & 99.1 & 0.1 \\
Picual & 5207 & 1109 & 3.0 & 1.2 & 83.7 & 10.2 & 125.0 & 92.2 & 6.6 \\
Selections & $2408-5711$ & $759-1570$ & $1.9-4.9$ & $0.8-2.1$ & $62.6-80.4$ & $10.4-30.7$ & $127.4-263.2$ & $95.8-98.2$ & $0.6-3.0$ \\
UC-I-22-90 & 4895 & 1563 & 4.1 & 1.2 & 75.8 & 16.4 & 129.3 & 96.8 & 2.1 \\
UC-I-2-35 & 4196 & 1068 & 3.7 & 0.8 & $\mathbf{6 2 . 6}^{\mathbf{a}}$ & $\mathbf{3 0 . 7 ^ { \mathbf { a } }}$ & 132.1 & 97.6 & 1.2 \\
UC-I-32-78 & 3311 & 1356 & 1.9 & 0.9 & 79.6 & 15.4 & 146.5 & 95.8 & 3.0 \\
UC-I-36-41 & 2408 & $\mathbf{7 5 9}$ & 4.0 & $\mathbf{2 . 1 ^ { \mathbf { a } }}$ & 69.0 & 22.4 & 165.6 & 98.2 & 0.6 \\
UC-I-36-43 & 3109 & 1570 & 2.9 & 1.3 & 76.7 & 17.8 & 129.4 & 97.9 & 0.7 \\
UC-I-37-69 & 2672 & 1107 & 4.9 & 1.7 & 80.4 & 10.4 & $\mathbf{2 6 3 . 2}$ & 97.2 & 1.9 \\
UC-I-42-48 & 5711 & 1288 & 2.1 & 0.9 & 75.8 & 19.4 & 127.4 & 97.4 & 1.5 \\
LSD 0.05 & 777 & 163 & 1.7 & 0.7 & 3.8 & 3.7 & 39 & 0.6 & 0.5 \\
\hline
\end{tabular}

${ }^{a}$ Values significantly lower or higher than those of the parents.
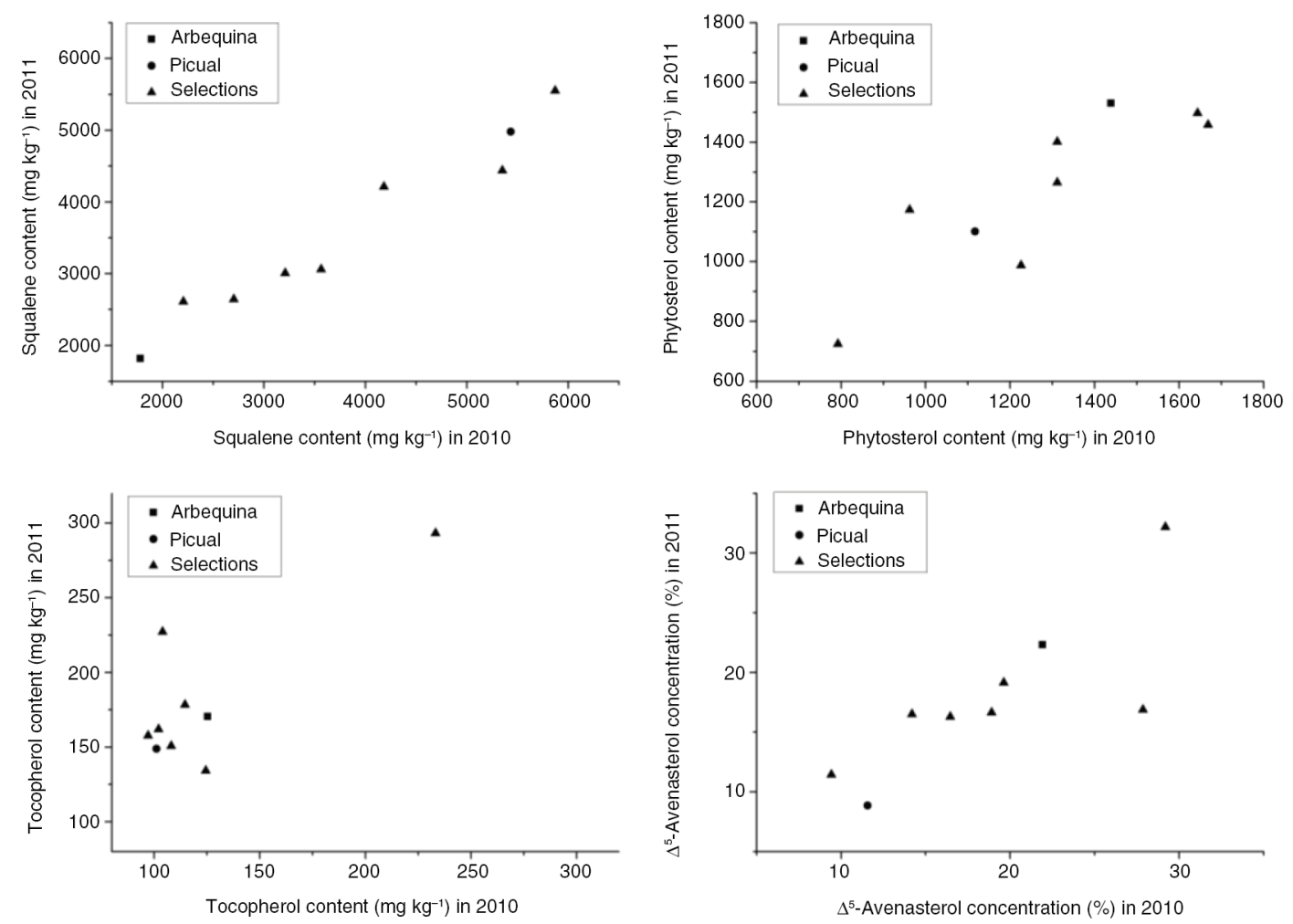

FIGURE 1. Values for squalene, phytosterol and tocopherol contents ( $\mathrm{mg} \cdot \mathrm{kg}^{-1}$ dry weight) and $\Delta^{5}$-avenasterol concentration ( $\%$ of total sterols) in the fruit flesh of olive cultivars 'Arbequina', 'Picual', and seven advanced selections derived from them, grown in Cabra (Córdoba, Spain) in 2010 and 2011.

the seven selections, except for the expected negative correlation between the major components of phytosterol and tocopherol profiles, i.e $\mathrm{r}=-0.96$ between the concentrations of $\beta$-sitosterol and $\Delta^{5}$-avenasterol, and $r=-0.99$ between the concentrations of $\alpha$ - and $\gamma$-tocopherol. Two-year average values for the parents and selections are shown in Table 3. It is important to emphasize that no significant correlations were detected between phytosterol contents and the levels of their common precursor, squalene. 


\section{DISCUSSION}

The analysis of variance revealed high genotype effects, non-significant or low-magnitude year effects, and genotype $\mathrm{x}$ year interactions of low magnitude. The main exception was total tocopherol content, for which a strong year effect was detected. Previous studies have associated total tocopherol content in olives with annual rainfall, with high annual rainfall reducing the tocopherol content (Beltrán et al., 2005; 2010). A similar effect has been observed in the present research; tocopherol contents in the genotypes included in the study averaged $123.3 \mathrm{mg} \cdot \mathrm{kg}^{-1}$ in 2010, which was a very wet year with an annual rainfall of $1058 \mathrm{~mm}$, whereas tocopherol content averaged $180.3 \mathrm{mg} \cdot \mathrm{kg}^{-1}$ in 2011 , a much dryer year with an annual rainfall of $491 \mathrm{~mm}$ (Table 1).

The cultivars 'Picual' and 'Arbequina' have contrasting oil qualities, particularly for fatty acid profile, squalene content, phytosterol content and profile, and total phenolic content (Allouche et al., 2007). Both cultivars differed largely for squalene content and phytosterol content and profile in the present study. One of the most relevant results of this research was that the progenies from crosses between both cultivars showed segregation for some traits that surpassed the values found in the parents, e.g. for total phytosterol and tocopherol contents, and for the concentrations of stigmasterol, $\beta$-sitosterol and $\Delta^{5}$-avenasterol. Broad segregation in olive progenies has been reported previously for reproductive traits (Ben Sadok et al., 2013) as well as for oil quality traits such as fatty acid profile, tocopherol content and profile, polyphenols, and carotenoids (León et al., 2011). The most interesting variation identified in the present research consisted of increased levels of $\Delta^{5}$-avenasterol $(30.7 \%$ of total sterols) in the selection UC-I-2-35 and tocopherols (263.2 $\mathrm{mg} \cdot \mathrm{kg}^{-1}$ fruit flesh) in the selection UC-I-37-69 (Table 3).

The typical range of variation of $\Delta^{5}$-avenasterol in olive oil is between 5 and $20 \%$ of total sterols (Boskou et al., 2006). Values up to $36 \%$ have been reported exceptionally in some Greek oils (Boskou et al., 2006), probably reflecting particular environmental and/or processing conditions. Sterol composition in olive oil is affected by cultivar, crop year, geographic factors, degree of fruit ripeness, storage time of fruits prior to oil extraction, and processing (Boskou et al., 2006). The cultivars with the highest $\Delta^{5}$-avenasterol content are Koroneiki (23.9\%) (Vekiari et al., 2010), Arbequina (23.2\%) (Gracia et al., 2009), and Leccino $(21.4 \%)$ (Gül and Seker, 2006). Accordingly, the high $\Delta^{5}$-avenasterol levels in the selection UC-I-2-35, observed in both years of the experiment (Figure 1), are exceptional within olive oil cultivars. Additional research should determine their effect on the oxidative stability of the olive oil.

Increasing tocopherol content is an important breeding objective for improving the nutritional quality of olive oil. The tocopherol content in virgin olive oil typically ranges from 100 to $250 \mathrm{mg} \cdot \mathrm{kg}^{-1}$ oil (Boskou, 2009), although higher values of up to 510 $\mathrm{mg} \cdot \mathrm{kg}^{-1}$ oil have been reported for some cultivars in single environments (Psomiadou et al., 2000; Beltrán et al., 2010). Tocopherol content is influenced by the same factors mentioned above for $\Delta^{5}$-avenasterol, i.e. cultivar, crop year, geographic factors, degree of fruit ripeness, storage time of fruits prior to oil extraction, and processing (Boskou et al., 2006). Nitrogen fertilization has also been found to influence tocopherol content in olive oil, with high fertilization levels decreasing tocopherol contents (Fernández-Escobar et al., 2006). The maximum average tocopherol content identified in the present research, $263.2 \mathrm{mg} \cdot \mathrm{kg}^{-1}$ fruit flesh in selection UC-I-37-69, was exceptionally high compared to the values found in both parents $\left(148 \mathrm{mg} \cdot \mathrm{kg}^{-1}\right.$ in 'Arbequina' and $125 \mathrm{mg} \cdot \mathrm{kg}^{-1}$ in 'Picual').

Virgin olive oil is the richest vegetable source of squalene, with typical levels between 200 and $7500 \mathrm{mg} \cdot \mathrm{kg}^{-1}$ (Boskou, 2009). The squalene content in olive oil mainly depends on the cultivar and the extraction and refining technologies (Wiesman, 2009; Nergiz and Çelikkale, 2011). The squalene content of the extracted oil has been reported to decrease during maturation (Sakohui et al., 2011; Ben Mansour et al., 2015a). However, FernándezCuesta et al. (2013) found that, at the fruit pulp level, squalene content was scarcely related to maturation. Squalene content has also been reported to be affected by the geographic area (Ben Mansour et al., 2015b) and agronomic practices such as irrigation (Martinelli et al., 2012). In the present research, one of the selections (UC-I-42-48) showed high squalene content. Although the squalene content of this selection was not significantly higher than the best parent, 'Picual', the values in the fruits of the selection were higher than in the parent in both years, i.e. $5871 \mathrm{mg} \cdot \mathrm{kg}^{-1}$ in UC-I-42-48 compared to $5434 \mathrm{mg} \cdot \mathrm{kg}^{-1}$ in 'Picual' in 2010, and $5552 \mathrm{mg} \cdot \mathrm{kg}^{-1}$ in UC-I-42-48 compared to $4980 \mathrm{mg} \cdot \mathrm{kg}^{-1}$ in 'Picual' in 2011 (Figure 1).

The genotypes included in this study are advanced selections of a breeding program in which the main initial selection criteria have been early bearing and high oil content. They have also been characterized for fatty acid profile and fruit traits (De la Rosa et al., 2013). The most promising selections in that research, UC-I-42-48 and UC-I-2-35, show other additional interesting oil quality attributes. For example, UC-I42-48 showed very high squalene content, whereas UC-I-2-35 showed very high $\Delta^{5}$-avenasterol content. Interestingly, the latter selection is also characterized by high oleic acid content (De la Rosa et al., 2013), which is one of the main factors contributing to oil thermo-stability (Allouche et al., 2007). Further research is required to investigate the contribution of $\Delta^{5}$-avenasterol to the thermo-stability of the oil as 
well as alleged synergistic effects between high oleic acid and high $\Delta^{5}$-avenasterol contents.

\section{CONCLUSIONS}

The present research identified great genetic variability for squalene and tocopherol contents and phytosterol content and profile in advanced olive selections, including phenotypes with higher levels than the parents for tocopherol content and $\Delta^{5}$-avenasterol concentration. These selections may play an important role in improving olive fruit and oil quality for specific market niches.

\section{ACKNOWLEDGMENTS}

The plant materials evaluated in this work were obtained from the cooperative breeding program carried out by the University of Córdoba and the Institute of Agricultural and Fishery Research and Training (IFAPA). The authors acknowledge the technical assistance of Angustias Jiménez-Muñoz and Plácida Nieto-Moreno.

\section{REFERENCES}

Allouche Y, Jiménez A, Gaforio JJ, Uceda M, Beltrán G. 2007. How heating affects extra virgin olive oil quality indexes and chemical composition. J. Agric. Food Chem. 55, 9646-9654. http://dx.doi.org/10.1021/jf070628u.

Aparicio R, Luna G. 2002. Characterisation of monovarietal virgin olive oils. Eur. J. Lipid Sci. Technol. 104, 614-627. http:// dx.doi.org/10.1002/1438-9312(200210)104:9/10<614::AIDEJLT614>3.0.CO;2-L

Ayton J, Mailer RJ, Robards K, Orchard B, Vonarx M. 2001. Oil concentration and composition of olives during fruit maturation in south-western New South Wales. Aust. J. Exp. Agr. 41, 815-821. http://dx.doi.org/10.1071/EA99116.

Baccouri B, Ben Temime S, Taamalli W, Daoud D, M'Sallem M, Zarrouk M. 2007. Analytical characteristics of virgin olive oils from two new varieties obtained by controlled crossing on Meski variety. J. Food Lipids 14, 19-34. http://dx.doi. org/10.1111/j.1745-4522.2006.00067.x.

Bellini E, Giordani E, Rosati A. 2008. Genetic improvement of olive from clonal selection to cross-breeding programs. Adv. Hortic. Sci. 22, 73-86.

Beltrán G, Aguilera MP, Del Rio C, Sanchez S, Martínez L. 2005. Influence of fruit ripening process on the natural antioxidant content of Hojiblanca virgin olive oils. Food Chem. 89 207-215. http://dx.doi.org/10.1016/j.foodchem.2004.02.027.

Beltrán G, Jiménez A, del Rio C, Sánchez S, Martínez L, Uceda M, Aguilera MP. 2010. Variability of vitamin E in virgin olive oil by agronomical and genetic factors. J. Food Comp. Anal. 23, 633-639. http://dx.doi.org/10.1016/j.jfca.2010.03.003.

Ben Mansour A, Flamini G, Ben Selma Z, Le Dréau Y, Artaud J, Abdelhedi R, Bouaziz M. 2015a. Olive oil quality is strongly affected by cultivar, maturity index and fruit part: Chemometrical analysis of volatiles, fatty acids, squalene and quality parameters from whole fruit, pulp and seed oils of two Tunisian olive cultivars. Eur. J. Lipid Sci. Technol. http://dx.doi.org/10.1002/ejlt.201400159.

Ben Mansour A, Gargouri B, Flamini G, Bouaziz M. 2015b. Effect of agricultural sites on differentiation between Chemlali and Neb Jmel olivel oils. J. Oleo Sci. 64, 381-392. http://dx.doi. org/10.5650/jos.ess 14204 .

Ben Sadok I, Celton JM, Essalouh L, El Aabidine AZ, Garcia G, Martinez S, Grati-Kamoun N, Rebai A, Costes E, Khadari B. 2013. QTL mapping of flowering and fruiting traits in olive.
PLoS One 8(5), e62831. http://dx.doi.org/10.1371/journal. pone. 0062831 .

Besnard G, Khadari B, Navascués M, Fernández-Mazuecos M, El Bakkali A, Arrigo N, Baali-Cherif D, Brunini-Bronzini de Caraffa V, Santoni S, Vargas P, Savolainen V. 2013. The complex history of the olive tree: from Late Quaternary diversification of Mediterranean lineages to primary domestication in the northern Levant. Proc. R. Soc. B 280, 20122833. http:// dx.doi.org/10.1098/rspb.2012.2833.

Boskou D. 2009. Other important minor constituents, in Boskou D (Ed.) Olive Oil. Minor Constituents and Health. CRC Press, Boca Raton, FL, USA, pp. 45-54.

Boskou D. 2011. Olive oil, in Gunstone F (Ed.) Vegetable Oils in Food Technology: Composition, Properties and Uses, $2^{\text {nd }} E d n$. Blackwell Publishing Ltd., Chichester, UK, pp. 243-272.

Boskou D, Blekas G, Tsimidou M. 2006. Olive oil composition, in Boskou D (Ed.) Olive Oil. Chemistry and Technology. AOCS Press, Champaign, IL, USA, pp. 41-72.

Byrne DH. 2012. Trends in fruit breeding, in Badenes ML, Byrne DH (Eds.) Fruit Breeding. Springer Science + Business Media, New York, pp. 3-36.

De la Rosa R, Talhaoui N, Rouis H, Velasco L, León L. 2013. Fruit characteristics and fatty acid composition in advanced olive breeding selections along the ripening period. Food Res. Int. 54, 1890-1896. http://dx.doi.org/10.1016/j.foodres. 2013.08.039.

Eitenmiller R, Lee J. 2004. Vitamin E. Food Chemistry, Composition, and Analysis. Marcel Dekker, New York.

El Riachy M, Priego-Capote F, León L, Luque de Castro MD, Rallo L. 2011. Virgin olive oil phenolic profile and variability in progenies from olive crosses. J. Sci. Food Agric. 92, 2524-2533. http://dx.doi.org/10.1002/jsfa.5662

Fabbri A, Lambardi M, Ozden-Tokatli Y. 2009. Olive breeding, in Jain SM, Priyadarshan PM (Eds.) Breeding Plantation Tree Crops: Tropical Species. Springer Science + Business Media LLC, New York, pp. 423-465.

Fernández-Cuesta A, León L, Velasco L, De la Rosa R. 2013. Changes in squalene and sterols associated with olive maturation. Food Res. Int. 54, 1885-1889. http://dx.doi. org/10.1016/j.foodres.2013.07.049

Fernandez-Escobar R, Beltran G, Sanchez-Zamora MA, GarciaNovelo J, Aguilera MP, Uceda M. 2006. Olive oil quality decreases with nitrogen over-fertilization, HortScience 41, 215-219.

Gómez-Rico A., Salvador MD, Moriana A, Pérez D, Olmedilla N, Ribas F, Fregapane G. 2007. Influence of different irrigation strategies in a traditional Cornicabra cv. olive orchard on virgin olive oil composition and quality. Food Chem. 100, 568-578. http://dx.doi.org/10.1016/j.foodchem.2005.09.075.

Gracia MS, Royo A, Guillén M. 2009. Composición química de aceites de las variedades Arbequina y Empeltre cultivadas en regadío. Grasas Aceites 60, 321-329. http://dx.doi. org/10.3989/gya.097008.

Gül MK, Seker M. 2006. Comparative analysis of phytosterol components from rapeseed (Brassica napus L.) and olive (Olea europaea L.) varieties. Eur. J. Lipid Sci. Technol. 108, 759-765. http://dx.doi.org/10.1002/ejlt.200600085.

Gunstone FD, Harwood JL. (2007) Occurrence and characterisation of oils and fats, in Gunstone FD, Harwood JL, Dijkstra AJ (Eds.) The Lipid Handbook, $3^{\text {rd }}$ Edn. CRC Press, Boca Raton, FL, USA, pp. 37-141.

León L, Rallo L, Del Río C, Martín LM. 2004. Variability and early selection on the seedling stage for agronomic traits in progenies from olive crosses. Plant Breeding 123, 73-78. http://dx.doi.org/10.1046/j.0179-9541.2003.00920.x

León L, De la Rosa R, Gracia A, Barranco D, Rallo L. 2008. Fatty acid composition of advanced olive selections obtained by crossbreeding. J. Sci. Food Agric. 88, 1921-1926. http:// dx.doi.org/10.1002/jsfa.3296.

León L, Beltrán G, Aguilera MP, Rallo L, Barranco D, De La Rosa R. 2011. Oil composition of advanced selections from an olive breeding program. Eur. J. Lipid Sci. Technol. 113, 870-875. http://dx.doi.org/10.1002/ejlt.201000535.

Manaï H, Mahjoub Haddada F, Trigui A, Daoud D, Zarrouk M. 2007. Compositional quality of virgin olive oil from two new 
Tunisian cultivars obtained through controlled crossings. J. Sci. Food Agric. 87, 600-606. http://dx.doi.org/10.1002/ jsfa. 2732 .

Martinelli F, Basile B, Morelli G, d'Andria R, Tonutti P. 2012. Effects of irrigation on fruit ripening behavior and metabolic changes in olive. Sci. Hort. 144, 201-207. http:// dx.doi.org/10.1016/j.scienta.2012.07.012.

Nergiz C, Çelikkale D. 2011. The effect of consecutive steps of refining on squalene content vegetale oils. J. Food Sci. Technol. 48, 382-385. http://dx.doi.org/10.1007/s13197-010-0190-2.

Perez-Jimenez F, Espino A, Lopez-Segura F, Blanco J, RuizGutierrez V, Prada JL, Lopez-Miranda J, Jimenez-Pereperez J, Ordovas JM. 1995. Lipoprotein concentrations in normolipidemic males consuming oleic acid-rich diets from two different sources: olive oil and oleic acid-rich sunflower oil. Am. J. Clin. Nutr. 62, 769-775.

Piironen V, Lindsay DG, Miettinen TA, Toivo J, Lampi AM. 2000. Plant sterols: biosynthesis, biological function and their importance to human nutrition. J. Sci. Food Agric. 80, 939-966. http://dx.doi.org/10.1002/(SICI)1097-0010 (20000515)80:7<939::AID-JSFA644>3.0.CO;2-C.

Psaltopoulou T, Naska A, Orfanos P, Trichopoulos D, Mountokalakis T, Trichopoulou A. 2004. Olive oil, the Mediterranean diet, and arterial blood pressure: the Greek European Prospective Investigation into Cancer and Nutrition (EPIC) study. Am. J. Clin. Nutr. 80, 1012-1018.

Psomiadou E, Tsimidou M, Boskou D. 2000. $\alpha$-Tocopherol content of Greek virgin olive oils. J. Agric. Food Chem. 48, 1770-1775. http://dx.doi.org/10.1021/jf990993o.

Ripa V, De Rose F, Caravita MA, Parise MR, Perri E, Rosati A, Pandolfi S, Paoletti A, Pannelli G, Padula G, Giordani E, Bellini E, Buccoliero A, Mennone C. 2008. Qualitative evaluation of olive oils from new olive selections and effects of genotype and environment on oil quality. $A d v$. Hortic. Sci. 22, 95-103.

Rjiba I, Dabbou S, Gazzah N, Hammami M. 2010. Effect of crossbreeding on the chemical composition and biological characteristics of Tunisian new olive progenies. Chem. Biodivers. 7, 649-655. http://dx.doi.org/10.1002/cbdv.200900092.

Rossell JB. 2001. Factors affecting the quality of frying oils and fats, in Rossell JB (Ed.) Frying: Improving Quality. CRC Press LLC, Boca Raton, FL, USA, pp. 115-164.

Sakouhi F, Herchi W, Sbei K, Absalon C, Boukhchina S. 2011. Characterisation and accumulation of squalene and $n$-alkanes in developing Tunisian Olea europaea L. fruits. Int. J. Food Sci. Technol. 46, 2281-2286. http://dx.doi.org/ 10.1111/j.1365-2621.2011.02747.x.

Sotiroudis TG, Kyrtopoulos SA. 2008. Anticarcinogenic compounds of olive oil and related biomarkers. Eur. J. Nutr. 47 (Suppl 2), 69-72. http://dx.doi.org/10.1007/s00394-0082008-9.

Vekiari SA, Oreopoulou V, Kourkoutas Y, Kamoun N, Msallem M, Psimouli V, Arapoglou D. 2010. Characterization and seasonal variation of the quality of virgin olive oil of the Throumbolia and Koroneiki varieties from Southern Greece. Grasas Aceites 61, 221-231. http://dx.doi.org/10.3989/gya. 108709.

Velasco L, Fernández-Cuesta A, De la Rosa R, Ruiz-Méndez MV, León L. 2014. Selection for some olive oil quality components through the analysis of fruit flesh. J. Am. Oil Chem. Soc. 91, 1731-1736. http://dx.doi.org/10.1007/s11746-014-2523-1.

Wiesman Z. 2009. Desert olive oil cultivation: Advanced biotechnologies. Academic Press, Burlington, MA, USA. 